\title{
Use of ebastine a mast cell blocker for treatment of oligozoospermia
}

\section{Farzana Deeba*, Shakeela Ishrat, Jesmine Banu, Shaheen Ara Anawary, Nurjahan Begum}

Department of Reproductive Endocrinology and Infertility, BSMMU, Dhaka, Bangladesh

Received: 25 December 2020

Revised: 11 March 2021

Accepted: 11 March 2021

\section{*Correspondence:}

Dr. Farzana Deeba,

E-mail: deeba_51@yahoo.com

Copyright: (c) the author(s), publisher and licensee Medip Academy. This is an open-access article distributed under the terms of the Creative Commons Attribution Non-Commercial License, which permits unrestricted non-commercial use, distribution, and reproduction in any medium, provided the original work is properly cited.

\section{ABSTRACT}

Background: Global infertility prevalence rates are difficult to determine, due to the presence of both male and female factors which complicate any estimate which may only address the woman and an outcome of a pregnancy diagnosis or live birth. Although overall male fertility does not appear to have declined, there is evidence for decline in sperm quality. Sperm count below $15 \times 106 \mathrm{sperm} / \mathrm{ml}$ is called oligozoospermia. The aim of this study was to evaluate the efficacy of ebastine on sperm count of oligospermic infertile men.

Methods: This was a longitudinal clinical trial study and was conducted in the infertility unit outdoor, Department of Obstetrics and Gynecology, Bangabandhu Sheikh Mujib Medical University, Dhaka. Bangladesh during the period from January 2015 to December 2015. This study was conducted among the male patients and followed purposive sampling technique. Finally, 334 cases were enrolled in this study.

Results: From the total 334 patients in group I, mean sperm count was $10.32 \pm 2.71$ million $/ \mathrm{ml}$ in pretreatment and $18.87 \pm 9.56 \mathrm{million} / \mathrm{ml}$ in post treatment. The difference was statistically significant $(\mathrm{p}<0.05)$. In group II, mean sperm count was $10.19 \pm 1.75 \mathrm{million} / \mathrm{ml}$ in pretreatment and $10.18 \pm 1.95 \mathrm{million} / \mathrm{ml}$ in post treatment. The difference was not statistically significant $(\mathrm{p}>0.05) .63 .9 \%$ oligospermic male showed improvement in sperm count in ebastin group and $18.1 \%$ in placebo group.

Conclusions: Sperm count had significantly improved after three months' treatment period with ebastin than placebo. Therefore, this study suggested that mast cell blocker ebastine can be helpful than placebo to improve the patients' sperm count with oligospermia.

Keywords: Male fertility, Mast cells, Oligozoospermia, Ebastine, Placebo

\section{INTRODUCTION}

Global infertility prevalence rates are difficult to determine, due to the presence of both male and female factors which complicate any estimate which may only address the woman and an outcome of a pregnancy diagnosis or live birth. Approximately $15 \%$ of human couples are infertile, and approximately $50 \%$ of this is because of male factors. ${ }^{1}$ Although overall male fertility does not appear to have declined, there is evidence for decline in sperm quality and a simultaneous increase in the number of infertile couples for last few decades. ${ }^{2}$ The above incidence has been estimated for the developed countries; however, proper estimates of incidence from most of the developing countries are not available. Mast cells are effectors cells of the immune system. Mast cells (MCs) were first described by Paul Ehrlich in 1878 (Mastzellen: well fed cells). In male reproductive organs, MCs were first described in the lamina propria of seminiferous tubules, but they are also found in the interstitial compartment of human testis, the epididymis and the excurrent ducts. ${ }^{3-6}$ Many studies have shown that MCs also play a crucial role in innate immunity. ${ }^{7-8}$ These data indicate that MCs function not only as sentinels but also as modulators of innate and adaptive immune responses, ultimately influencing disease outcomes. The release of tryptase by MCs in the testis has been associated 
with fibrotic remodeling in defective spermatogenesis of infertile men and sperm number and quality decrease under chronically testicular inflammatory conditions. ${ }^{9-10}$ Sperm count below $15 \times 10^{6} \mathrm{sperm} / \mathrm{ml}$ is called oligozoospermia. ${ }^{11} 50 \%$ improvement of baseline sperm count regarded as improvement. So, the treatment of patients suffering from oligozoospermia with MC blockers were found to have some improved semen parameters by many authors. ${ }^{11-13}$

The right treatment of male infertility is relatively costly procedure. In our country due to ignorance of the patients, lack of sharp cut technology in every level sometime people are misguided by various type of treatment procedures. Maximum people of our country lives below the standard level economical parameter. So we should sincerer about the treatment procedure and find out the role of mast cell blocker ebastin and placebo in male infertility for the sake of the wellbeing of our people.

This study will help our people to save their hard earnings as well as infertility service provider to take proper action in improvement of abnormal semen parameters in the population of low resource country. The study aims to evaluate the efficacy of MC blocker ebastin in the improvement of sperm count in oligospermic male infertility.

\section{General objective}

General objective of the study was to evaluate the efficacy of MC blocker ebastin in the improvement of sperm count male infertility due to oligozoospermia.

\section{Specific objectives}

Specific objectives of the study were to describe a demographic chart, personal and family history of the study people and to find out the effect of ebastin upon sperm count.

\section{METHODS}

This was a longitudinal clinical trial study conducted in the infertility unit outdoor, Department of Obstetrics and Gynecology, Bangabandhu Sheikh Mujib Medical University, Dhaka. Bangladesh during the period from January 2015 to December 2015.

This study was conducted among the male patients presented to the study place during study period with infertility which is not attributable to any endocrine or urological abnormality and followed purposive sampling technique. A total of 340 infertility patients were included in this study with maintaining inclusion criteria, and among them 6 patients were excluded from the study due to dropout (not came during follow-up). Finally, 167 cases were given ebastin as group I and 167 patients were given only placebo as group II.

\section{Inclusion criteria}

All the male patients with infertility with following criteria: age 25-50 years and abnormal semen parameter of oligospermia were included in the study.

\section{Exclusion criteria}

Patients with age less than 25 years or more than 50 years, abnormalities in reproductive organ, known hormonal disorder, known medical disorder, psychosexual abnormalities and urological abnormality were excluded from the study.

Finally, 334 cases were enrolled in this study. Among the male with abnormal semen parameter, 106 patients were oligospermic and 60 patients were combined oligoasthenozoospermic. Alternate patient was administered, tablet ebastin $10 \mathrm{mg}$ and placebo twice daily and follow up semen analysis was done at pre fixed schedule after 3 months to analyze the changes that is achieved. Ethical clearance was taken from the local ethical committee to perform investigation and study. Statistical analysis was carried out by using the statistical package for social sciences version 16.0 for Windows (SPSS Inc., Chicago, Illinois, USA) and Microsoft Excel 2016. The mean values were calculated by frequencies and percentages. The quantitative observations were indicated by frequencies and percentages. Chi square test was used for categorical variables. Unpaired and paired t-test was used for continuous variables. $\mathrm{P}$ values $<0.05$ was considered as statistically significant.

\section{RESULTS}

Demographic variable of the patients. It was observed that majority patients belonged to age 31-40 years in both groups, which was $106(63.5 \%)$ in group I and 108 (64.7\%) in group II. The mean age was found $35.8 \pm 5.8$ years in group I and 34.9 \pm 6.1 years in group II. The difference was not statistically significant ( $p>0.05$ ) (Figure 1). Regarding sexual dysfunction, it was observed that no sexual dysfunction was found $155(92.8 \%)$ in group I and 160 $(95.8 \%)$ in group II. Mean staging together was found $5.8 \pm 4.1$ years in group I and 5.6 \pm 3.9 years in group II. Mean coital frequency was found $2.8 \pm 0.9$ years in group I and 2.6 \pm 1.1 years in group II. Primary infertility was found $130(77.8 \%)$ in group I and $115(68.9 \%)$ in group II. Mean duration of infertility was found $149(89.2 \%)$ in group I and $161(96.4 \%)$ in group II (Table 1). Majority 135 $(80.8 \%)$ patients non-smokers in group I and $141(84.4 \%)$ in group II. Smoker was found $32(19.2 \%)$ in group I and $26(15.6 \%)$ in group II. Mean duration of smoking was found 12.0 \pm 6.7 years in group I and 5.9 \pm 4.7 years in group II. Majority $164(98.2 \%)$ patients in group I and 166 $(99.4 \%)$ in group II were not taken alcohol. The difference was not statistically significant $(\mathrm{p}>0.05)$ (Table 2$)$. It was observed that majority $115(68.9 \%)$ patients in group I and $128(76.6 \%)$ patients in group II patients had no family history. $34(20.4 \%)$ patients had diabetes mellitus (DM) in 
group I and $26(15.6 \%)$ in group II. $13(7.8 \%)$ and $9(5.4 \%)$ had infertility in group I and group II respectively. The difference was not statistically significant $(\mathrm{p}>0.05)$ (Table 3 ). It was observed that mean serum thyroid stimulating hormone (TSH) was found $2.3 \pm 1.9 \mathrm{miu} / \mathrm{ml}$ in group I and $2.4 \pm 2.0 \mu / \mathrm{ml}$ in group II. Mean prolactine was $8.0 \pm 4.0$ $\mathrm{ng} / \mathrm{dl}$ in group I and $7.8 \pm 4.1 \mathrm{ng} / \mathrm{dl}$ in group II. Mean serum free testostosterone was found $12.3 \pm 8.5 \mathrm{ng} / \mathrm{dl}$ and $12.1 \pm 8.4 \mathrm{ng} / \mathrm{dl}$ in group I and group II respectively. The difference was not statistically significant $(\mathrm{p}>0.05)$ (Table 4).

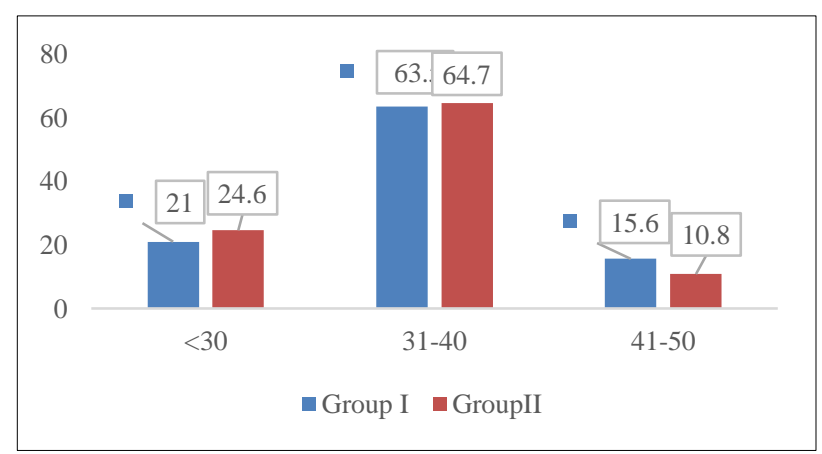

Figure 1: Distribution of the study patients by age variable $(\mathrm{N}=334)$.
In group I, mean sperm count was $10.32 \pm 2.71$ million $/ \mathrm{ml}$ in pretreatment and $18.87 \pm 9.56 \mathrm{million} / \mathrm{ml}$ in post treatment. The difference was statistically significant $(\mathrm{p}<0.05)$. In group II, mean sperm count was $10.19 \pm 1.75$ million $/ \mathrm{ml}$ in pretreatment and $10.18 \pm 1.95$ million $/ \mathrm{ml}$ in post treatment. The difference was not statistically significant ( $p>0.05$ ) (Table 5). 63.9\% oligospermic male showed improvement in sperm count in ebastin group and $18.1 \%$ in placebo group. Which was statistically significant $(\mathrm{p}<0.05)$ (Figure 2$)$.

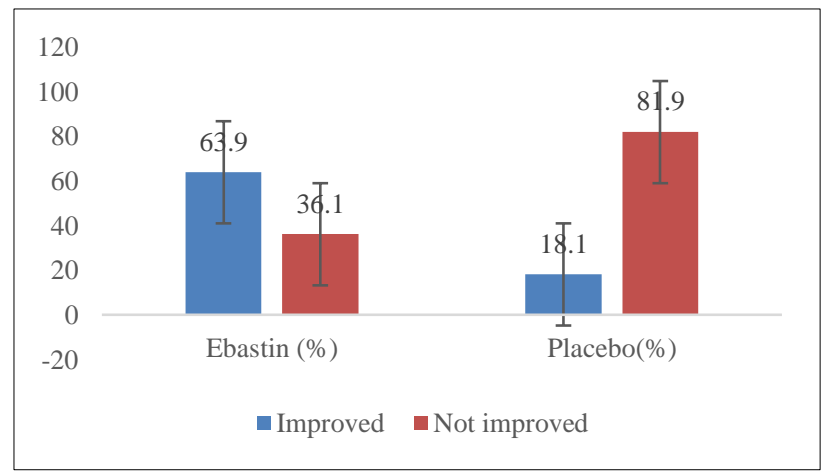

Figure 2: Improvement of sperm count (ebastin $\mathrm{N}=84$ ); (placebo $\mathrm{N}=84$ ).

Table 1: Distribution of the study patients by personal history $(\mathrm{N}=334)$.

\begin{tabular}{|c|c|c|c|c|c|}
\hline \multirow{2}{*}{ History } & \multicolumn{2}{|l|}{ Group I } & \multicolumn{2}{|c|}{ Group II } & \multirow{2}{*}{ P value } \\
\hline & n & $\%$ & n & $\%$ & \\
\hline \multicolumn{6}{|l|}{ Sexual dysfunction } \\
\hline Impotency & 5 & 3 & 3 & 1.8 & \multirow{3}{*}{${ }^{\mathrm{a}} 0.497^{\mathrm{ns}}$} \\
\hline Premature ejaculation & 7 & 4.7 & 4 & 2.4 & \\
\hline No & 155 & 92.8 & 160 & 95.8 & \\
\hline \multicolumn{6}{|c|}{ Staying together (in years) } \\
\hline Mean \pm SD & $5.8 \pm 4.1$ & & $5.6 \pm 3.9$ & & \multirow{2}{*}{${ }^{\mathrm{b}} 0.648^{\mathrm{ns}}$} \\
\hline Range (min-max) & $0.2-19$ & & $0.5-11$ & & \\
\hline \multicolumn{6}{|c|}{ Coital frequency (in weeks) } \\
\hline Mean \pm SD & $2.8 \pm 0.9$ & & $2.6 \pm 1.1$ & & \multirow{2}{*}{${ }^{\mathrm{b}} 0.070^{\mathrm{ns}}$} \\
\hline Range (min-max) & $1-5$ & & $1-5$ & & \\
\hline \multicolumn{6}{|l|}{ Type of infertility } \\
\hline Primary & 130 & 77.8 & 115 & 68.9 & \multirow{2}{*}{${ }^{\mathrm{a}} 0.063^{\text {ns }}$} \\
\hline Secondary & 37 & 22.2 & 52 & 31.1 & \\
\hline \multicolumn{6}{|c|}{ Duration of infertility (in years) } \\
\hline$\leq 10$ & 149 & 89.2 & 161 & 96.4 & \\
\hline$>10$ & 18 & 10.8 & 6 & 3.6 & \\
\hline Mean \pm SD & $5.15 \pm 3.83$ & & $5.1 \pm 4.1$ & & \multirow{2}{*}{${ }^{\mathrm{b}} 0.908^{\mathrm{ns}}$} \\
\hline Range (min-max) & $0.5-18$ & & $1-15$ & & \\
\hline
\end{tabular}

ns=not significant, $\mathrm{a}=\mathrm{P}$ value reached from unpaired $\mathrm{t}$-test, $\mathrm{b}=\mathrm{P}$ value reached from chi square test

Table 2: Distribute the study people according to the risk factors $(\mathrm{N}=334)$.

\begin{tabular}{|c|c|c|c|c|c|}
\hline \multirow{2}{*}{ Risk factors } & \multicolumn{2}{|c|}{ Group I } & \multicolumn{2}{|c|}{ Group II } & \multirow{2}{*}{$P$ value } \\
\hline & $\mathbf{n}$ & $\%$ & n & $\%$ & \\
\hline \multicolumn{6}{|l|}{ Smoking } \\
\hline Yes & 32 & 19.2 & 26 & 15.6 & \multirow{2}{*}{${ }^{\mathrm{a}} 0.386^{\mathrm{ns}}$} \\
\hline No & 135 & 80.8 & 141 & 84.4 & \\
\hline
\end{tabular}

Continued. 


\begin{tabular}{|c|c|c|c|c|c|}
\hline \multirow{2}{*}{ Risk factors } & \multicolumn{2}{|l|}{ Group I } & \multicolumn{2}{|l|}{ Group II } & \multirow{2}{*}{ P value } \\
\hline & n & $\%$ & $\mathbf{n}$ & $\%$ & \\
\hline \multicolumn{6}{|l|}{ Stick per day } \\
\hline Mean $\pm S D$ & $6.4 \pm 6.97$ & & $5.9 \pm 4.7$ & & ${ }^{\mathrm{b}} 0.443^{\mathrm{ns}}$ \\
\hline Range (min-max) & $1-30$ & & $0.5-24$ & & \\
\hline \multicolumn{6}{|c|}{ Duration of smoking (in years) } \\
\hline Mean \pm SD & $12 \pm 6.7$ & & $10.9 \pm 5.9$ & & ${ }^{\mathrm{b}} 0.112^{\mathrm{ns}}$ \\
\hline Range (min-max) & $0.2-30$ & & $0.5-24$ & & \\
\hline \multicolumn{6}{|l|}{ Alcohol } \\
\hline No & 164 & 98.2 & 166 & 99.4 & ${ }^{\mathrm{a}} 0.311^{\mathrm{ns}}$ \\
\hline Occasional & 3 & 1.8 & 1 & 0.6 & \\
\hline \multicolumn{6}{|l|}{ Other drugs } \\
\hline Yes & 0 & 0 & 0 & 0 & \\
\hline No & 167 & 100 & 167 & 100 & \\
\hline
\end{tabular}

$\mathrm{ns}=$ not significant, $\mathrm{a}=\mathrm{P}$ value reached from unpaired $\mathrm{t}$-test, $\mathrm{b}=\mathrm{P}$ value reached from chi square test

Table 3: Distribution of the study patients by family history $(\mathrm{N}=334)$.

\begin{tabular}{|c|c|c|c|c|c|}
\hline \multirow{2}{*}{ Family history } & \multicolumn{2}{|c|}{ Group I } & \multicolumn{2}{|c|}{ Group II } & \multirow{2}{*}{ P value } \\
\hline & $\mathbf{n}$ & $\%$ & $\mathbf{n}$ & $\%$ & \\
\hline DM & 34 & 20.4 & 26 & 15.6 & \multirow{4}{*}{$0.457^{\mathrm{ns}}$} \\
\hline Infertility & 13 & 7.8 & 9 & 5.4 & \\
\hline TB & 5 & 3 & 4 & 2.4 & \\
\hline No family history & 115 & 68.8 & 128 & 76.6 & \\
\hline
\end{tabular}

$\mathrm{ns}=$ not significant

Table 4: Distribution of the study patients by endocrine evaluation ( $N=334)$.

\begin{tabular}{|c|c|c|c|}
\hline Endocrine evaluation & Group I (n=167) & Group II (n=167) & P value \\
\hline \multicolumn{4}{|l|}{ Serum TSH (miu/ml) } \\
\hline Mean \pm SD & $2.3 \pm 1.9$ & $2.4 \pm 2.0$ & \multirow{2}{*}{$0.640^{\mathrm{ns}}$} \\
\hline Range (min-max) & $0.26-8.95$ & $0.31-9.2$ & \\
\hline \multicolumn{4}{|l|}{ Prolactine (ng/dl) } \\
\hline Mean \pm SD & $8 \pm 4.0$ & $7.8 \pm 4.1$ & \multirow{2}{*}{$0.652^{\text {ns }}$} \\
\hline Range (min-max) & $2.2-29.8$ & $2.1-16.2$ & \\
\hline \multicolumn{4}{|c|}{ Serum free testostosterone (ng/dl) } \\
\hline Mean \pm SD & $12.3 \pm 8.5$ & $12.1 \pm 8.4$ & \multirow{2}{*}{$0.829^{\text {ns }}$} \\
\hline Range (min-max) & $2.5-39.6$ & $2.4-31.2$ & \\
\hline
\end{tabular}

ns=not significant

Table 5: Pretreatment and post treatment difference in sperm count of isolated oligospermia ( $N=334)$.

\begin{tabular}{|c|c|c|c|}
\hline Sperm count (million/ml) & Pretreatment & Post treatment & P value \\
\hline \multicolumn{4}{|l|}{ Group I $(n=53)$} \\
\hline Mean \pm SD & $10.32 \pm 2.71$ & $18.87 \pm 9.56$ & \multirow{2}{*}{${ }^{\mathrm{a}} 0.001^{\mathrm{s}}$} \\
\hline Range (min-max) & $3-14$ & $7-60$ & \\
\hline \multicolumn{4}{|l|}{ Group II (n=53) } \\
\hline Mean \pm SD & $10.19 \pm 1.75$ & $10.81 \pm 1.95$ & \multirow{2}{*}{${ }^{\mathrm{a}} 0.715^{\mathrm{ns}}$} \\
\hline Range (min-max) & $3-11$ & $6-12$ & \\
\hline $\mathrm{P}$ value & ${ }^{\mathrm{b}} 0.770^{\mathrm{ns}}$ & ${ }^{b} 0.00^{s}$ & \\
\hline
\end{tabular}

$\mathrm{ns}=$ not significant, $\mathrm{a}=\mathrm{P}$ value reached from unpaired $\mathrm{t}$-test

\section{DISCUSSION}

This longitudinal clinical trial was carried out with an aim to determine the effect of MC blocker ebastin upon sperm count of oligospermic male infertility. MCs play a key role in the inflammation, hypersensitivity and fibrosis, are as well normally present in the testes. ${ }^{10,15}$ Roaiah study suggest that there is a prominent increase in the number of testicular MCs in the testes of infertile men which may disrupt spermatogenesis. ${ }^{16}$ Also, it was reported that 
increased numbers of MCs have been associated with different types of infertility, including asthenospermia. ${ }^{16,17}$ Therefore, some of male factor infertility problems could possibly diminished if such pathogenesis agent would greatly reduce using drug that block MC mediator release. All the male patients with infertility with age belonged to 25-50 years, abnormal semen parameters i.e. oligospermia not attributable to any endocrine or urological abnormality were enrolled in this study. Age less than 25 years or more than 50 years, abnormalities in reproductive organ, known hormonal disorder, known medical disorder, psychosexual abnormalities and urological abnormality were excluded from the study. In this present study it was observed that majority patients belonged to age 31-40 years in both groups, which was $106(63.5 \%)$ in group I and $108(64.7 \%)$ in group II. The mean age was found $35.8 \pm 5.8$ years in group I and $34.9 \pm 6.1$ years in group II. The difference was not statistically significant $(\mathrm{p}>0.05)$. Saharkhiz found the male were aged 23-40 years of mean age 32.8 years, which is consistent with the current study. ${ }^{18}$ Similarly, Multigner and Cayan showed the mean age of the infertile male patients were 32.0 years varied from 22 to 47 years and $34.5 \pm 7.2$ years varied from 24 to 49 years respectively. ${ }^{19,20}$ Similar, age range also observed by Roaiah and Hussein in their respective studies. ${ }^{16,21}$ On the other hand, El-Karaksy showed $64.0 \%$ were in more than 40 years and $36.0 \%$ were in under 40 years, which is higher with the current study, the higher age range maybe due to geographical variations, racial, ethnic differences and different lifestyle may have significant influence to identified their infertility. ${ }^{22}$ Prostatitis causes substantial morbidity to men, through associated urinary symptoms, sexual dysfunction, and pelvic pain; however, $90 \%$ to $95 \%$ of cases have an unknown etiology obtained by Ellem. ${ }^{23}$ Regarding sexual dysfunction, no sexual dysfunction was found $155(92.8 \%)$ in group I and $160(95.8 \%)$ in group II. Mean staging together was found 5.8 \pm 4.1 years in group I and 5.6 \pm 3.9 years in group II. Mean coital frequency was found $2.8 \pm 0.9$ years in group I and 2.6 \pm 1.1 years in group II. The difference was not statistically significant $(\mathrm{p}>0.05)$. In this current study it was observed that majority $135(80.8 \%)$ patient's nonsmokers in group I and $141(84.4 \%)$ in group II. Smoker was found $32(19.2 \%)$ in group I and 26 $(15.6 \%)$ in group II. Mean duration of smoking was found $12.0 \pm 6.7$ years in group I and $5.9 \pm 4.7$ years in group II. Majority 164 (98.2\%) patients in group I and 166 (99.4\%) in group II were not taken alcohol. The difference was not statistically significant $(\mathrm{p}>0.05)$. Seminal mast cells showed higher frequency among smokers compared with non-smokers, suggesting an etiological relationship between smoking and mast cell abundance in infertile patients, and therefore an indirect relationship between smoking and infertility. This supports the studies that establish smoking as having an adverse effect on fertility, especially on progressive sperm motility, irrespective of total amount of cigarettes smoked per day. ${ }^{24,25}$ In this study it was observed that majority $115(68.9 \%)$ patients in group I and $128(76.6 \%)$ patients in group II patients had no family history. 34 (20.4\%) patients had DM in group I and $26(15.6 \%)$ in group II. $13(7.8 \%)$ and $9(5.4 \%)$ had infertility in group I and group II respectively. The difference was not statistically significant $(p>0.05)$. In this present study it was observed that mean serum TSH was found $2.3 \pm 1.9 \mathrm{miu} / \mathrm{ml}$ in group I and $2.4 \pm 2.0 \mu / \mathrm{ml}$ in group II. Mean prolactine was $8.0 \pm 4.0 \mathrm{ng} / \mathrm{dl}$ in group I and $7.8 \pm 4.1 \mathrm{ng} / \mathrm{dl}$ in group II. Mean serum free testostosterone was found $12.3 \pm 8.5 \mathrm{ng} / \mathrm{dl}$ and $12.1 \pm 8.4 \mathrm{ng} / \mathrm{dl}$ in group I and group II respectively. The difference was not statistically significant $(\mathrm{p}>0.05)$. Cayan showed the serum testosterone values was $5.5 \pm 2.6 \mathrm{ng} / \mathrm{ml}$ varied from 1.7 to $12.6 \mathrm{ng} / \mathrm{ml}$, which is lesser with the present study. ${ }^{20}$ Ketotifen's (MC blocker) androgenic effects on male infertility, associated with oligospermia have been reported by Olivia and Multigner. ${ }^{26}$ Studies have also shown that it may counteract the ability of MCs to trigger an inflammatory response. It is worth mentioning that the number of MCs sometimes increases more than normal in the testicular tissue of infertile men. ${ }^{27}$ In another study Schill also suggested that ketotifen (MC blocker) can be more helpful to improve the patients' sperm count and sperm motility with idiopathic oligospermia. ${ }^{11}$ In this current study it was observed that in group I, mean sperm count was $10.32 \pm 2.71 \mathrm{million} / \mathrm{ml}$ in pretreatment and $18.87 \pm 9.56 \mathrm{million} / \mathrm{ml}$ in post treatment. The difference was statistically significant $(\mathrm{p}<0.05)$. In group II, mean sperm count was $10.19 \pm 1.75 \mathrm{million} / \mathrm{ml}$ in pretreatment and $10.18 \pm 1.95$ million $/ \mathrm{ml}$ in post treatment. The difference was not statistically significant $(\mathrm{p}>0.05)$. In this study $63.9 \%$ oligospermic male showed improvement in sperm count in ebastin group and $18.1 \%$ in placebo group. Which was statistically significant $(\mathrm{p}<0.05)$. Matsuki investigated the effect of ebastine, a MC blocker, on semen quality in idiopathic oligozoospermic men reporting $66.7 \%$ of the patients had improved semen quality. ${ }^{28}$ Olivia and Multigner carried out a study to assess the efficacy of daily administration of ketotifen (MC blocker), on the semen quality of men with leukocytospermia and unexplained infertility. ${ }^{26}$ They noticed that ketotifen diminished the white blood cell count in semen and so the sperm motility has been dramatically improved. Moreover, the number of morphologically normal spermatozoa was more pronounced at 8 weeks of treatment and these changes remained until at least 4 weeks after stopped of ketotifen (MC blocker) treatment. Ketotifen (MC blocker) was used several years ago for treating patients with idiopathic oligozoospermia and asthenozoospermia (independent of the presence of leukocytospermia). This led to a very moderate but statistically significant improvement in sperm count. ${ }^{11}$ Matsuki showed that the mast cell blocker ebastine significantly improved semen quality in idiopathic oligozoospermia. ${ }^{28} \mathrm{Hibi}$ reported that tranilast improved semen parameters in severe oligozoospermia, but not for long-term administration. ${ }^{13}$ Matsuki observed the effect of MC blocker (ebastine) on semen quality was evaluated in 15 idiopathic oligozoospermic males and $66.7 \%$ showed definite improvement in the semen quality. ${ }^{28}$ It would appear that MC blocker (ebastine) significantly improves semen quality in men with idiopathic oligozoospermia. Nagai had shown that the number of MCs in testicular tissue was 
increased and the ratio of mast cell subtypes (chymase and tryptase) was changed in idiopathic oligozoospermia. ${ }^{29}$ Yamamoto prescribed randomly MC blocker (tranilast) or placebo for 3 months' infertile males with severe idiopathic oligozoospermia, showing significant improvement in semen parameters. ${ }^{30}$

\section{Limitations}

The study population was selected from one selected tertiary hospital in Dhaka city, so that the results of the study may not reflect the exact picture of the community.

\section{CONCLUSION}

From this paper we found that sperm count had significantly improved after three months' treatment period with ebastin. Therefore, this study suggested that MC blocker ebastin can be helpful to improve the patients' sperm count of oligospermic male infertility. Further community based or multicenter, double blind placebo controlled studies can be undertaken by including large number of patients and Ebastin can be given to the oligospermic men before intrauterine insemination (IUI) or ART cycles of treatment.

\section{Funding: No funding sources}

Conflict of interest: None declared

Ethical approval: The study was approved by the Institutional Ethics Committee

\section{REFERENCES}

1. Bhasin S, de Kretser DM, Baker HW. Clinical review 64: pathophysiology and natural history of male infertility. J Clin Endocrinal Metab. 194;79(6):15259.

2. Auger J, Kunstmann JM, Czyglik F, Jouannet P. Decline in semen quality among fertile men in Paris during the past 20 years. $\mathrm{N}$ Engl $\mathrm{J}$ Med. 1995;332(5):281-5.

3. Hermo L, Lalli M. Monocytes and mast cells in the limiting membrane of human seminiferous tubules. Biol Reprod. 1978;19(1):92-100.

4. Behrendt H, Hilscher B, Passia D, Hofmann $\mathrm{N}$, Hilscher W. The occurrence of mast cells in the human testis. Acta Anat. 1981;111:14-6.

5. Maseki Y, Miyake K, Mitsuya H, Kitamura H, Yamada K. Mastocytosis occurring in the testes from patients with idiopathic male infertility. Fertil Steril. 1981;36(6):814-7.

6. Nistal M, Santamaria L, Paniagua R. Mast cells in the human testis and epididymis from birth to adulthood. Acta Anat. (Basel). 1984;119(3):155-60.

7. Mekori YA, Metcalfe DD. Mast cells in innate immunity. Immunol Rev. 2000;173:131-40.

8. Metz M, Maurer M. Mast cells - key effector cells in immune responses. Trends Immunol. 2007;28(5):23441.
9. Pejler G, Abrink M, Ringvall M, Wernersson S. Mast cell proteases. Adv Immunol. 2007;167-255.

10. Pejler G, Ronnberg E, Waern I, Wernersson S. Mast cell proteases: multifaceted regulators of inflammatory disease. Blood. 2010;115(24):4981-90.

11. Schill WB, Schneider J, Ring J. The use of ketotifen, a mast cell blocker, for treatment of oligo-and asthenozoospermia. Andrologia. 1986;18(6):570-3.

12. Yamamoto M, Hibi H, Miyake K. Appearance of spermatozoon after administration of mast cell blocker to a patient with azoospermia. Hinyokika Kiyo. 1994;40(6):541-3.

13. Hibi H, Kato K, Mitsui $K$. The treatment with tranilast, a mast cell blocker, for idiopathic oligozoospermia. Arch Androl. 2001;47(2):107-11.

14. Winters BR, Walsh TJ. The Epidemiology of Male Infertility. Urol Clin N Am. 2014;41:195-204.

15. Chakraborty S, Bonthu N, Swanson BJ, Batra SK. Role of mucins in the skin during benign and malignant conditions. Cancer Lett. 2011;301:127-41.

16. Roaiah MM, Khatab H, Mostafa T. Mast cells in testicular biopsies of azoospermic men. Andrologia. 2007;39(5):185-9.

17. Haidl G, Duan YG, Chen SJ, Kohn FM, Schuppe HC, Allam JP. The role of mast cells in ale infertility. Expert Rev Clin Immunol. 2011;7:627-34.

18. Saharkhiz N, Nikbakht R and Hemadi M. Ketotifen, a mast cell blocker improves sperm motility in asthenospermic infertile men. J Hum Reprod Sci. 2013;6(1):19-22.

19. Multigner L. Ketotifen improves sperm motility and sperm morphology in male patients with leukocytospermia and unexplained infertility. Fertil Steril. 2006;85:240-3.

20. Cayan S, Apa DD, Akbay E. Effect of fexofenadine, a mast cell blocker, in infertile men with significantly increased testicular mast cells. Asian J Androl. 2002;4(4):291-4.

21. Hussein MR, Abou-Deif ES, Bedaiwy MA. Phenotypic characterization of the immune and mast cell infiltrates in the human testis shows normal and abnormal spermatogenesis. Fertil Steril. 2005;83(5):1447-53.

22. El-Karaksy A, Mostafa T, Shaeer OK, Bahgat DR, Samir N. Seminal mast cells in infertile asthenozoospermic males. Andrologia. 2007;39(6):244-7.

23. Ellem SJ, Wang $H$, Poutanen M, Risbridger GP. Increased endogenous estrogen synthesis leads to the sequential induction of prostatic inflammation (prostatitis) and prostatic pre-malignancy. Am J Pathol. 2009;175(3):1187-99.

24. Hassa H, Yildirim A, Can C, Turgut M. Effect of smoking on semen parameters of men attending an infertility clinic. Clin Exp Obstet Gynecol. 2006;33:19-22.

25. Mostafa T, Tawadrous G, Roaih MMF, Amer M, Ashour S, Aziz A. Effect of smoking on seminal plasma ascorbic acid in infertile and fertile males. Andrologia. 2006;38:221-4. 
26. Oliva A, Multigner L. Ketotifen improves sperm motility and sperm morphology in male patients with leukocytospermia and unexplained infertility. Fertil Steril. 2006;85(1):240-3.

27. Moskovtsev SI, Willis J, White J, Mullen JB. Leukocytospermia: Relationship to sperm deoxyribonucleic acid integrity in patients evaluated for male factor infertility. Fertil Steril. 2007;88:73740.

28. Matsuki S, Sasagawa I, Suzuki Y. The use of ebastine, a mast cell blocker, for treatment of oligozoospermia. Arch Androl. 2000;44(2):129-32.

29. Nagai T, Takaba H, Miyake K, Hirabayashi Y, Yamada K. Testicular mast cell heterogeneity in idiopathic male infertility. Fertil Steril. 1992;57(6):1331-6.

30. Yamamoto M, Hibi H, Miyake K. New treatment of idiopathic severe oligozoospermia with mast cell blocker: results of a single-blind study. Fertil Steril. 1995;64(6):1221-3.

Cite this article as: Deeba $\mathrm{F}$, Ishrat $\mathrm{S}$, Banu J, Anawary SA, Begum N. Use of ebastine a mast cell blocker for treatment of oligozoospermia. Int $\mathbf{J}$

Reprod Contracept Obstet Gynecol 2021;10:1763-9. 